\title{
Critical Thinking Analysis of 13-14 Years Old Students on Lens Refraction Material
}

\author{
Tanti $^{1}$, Darmaji ${ }^{2}$, Astalini ${ }^{3}$, Dwi Agus Kurniawan ${ }^{4 *}$, Lia Kartina ${ }^{5}$ \\ ${ }^{1}$ Faculty of Science and Technology, Universitas Islam Negeri Sultan Thaha Saifuddin, Jambi \\ 2, 3, 4, 5 Departement of Physics Education, Faculty of Teacher and Education, Jambi University \\ *Corresponding Address: dwiagus.k@unja.ac.id
}

\begin{tabular}{|c|c|}
\hline Article Info & ABSTRACT \\
\hline Article history: & $\begin{array}{l}\text { This research aims to analyze HOTS-based science learning in terms of } \\
\text { students' critical thinking skills. This research was conducted at SMPN } 22\end{array}$ \\
\hline $\begin{array}{l}\text { Received: September } 14^{\text {th }}, 2020 \\
\text { Accepted: April } 26^{\text {th }}, 2021 \\
\text { Published: May } 5^{\text {th }}, 2021\end{array}$ & $\begin{array}{l}\text { Jambi City using a mixed research method with explanatory design analysis. } \\
\text { Two instruments were made in this research: the description test questions as } \\
\text { an instrument for quantitative approach and interviews for qualitative }\end{array}$ \\
\hline Keywords: & $\begin{array}{l}\text { selected using quota sampling. The tested topic was the lens refraction which } \\
\text { consisted of } 10 \text { questions. Five indicators were tested: namely, the ability to }\end{array}$ \\
\hline $\begin{array}{l}\text { Critical Thinking, } \\
\text { HOTS, } \\
\text { Natural Sciences. }\end{array}$ & $\begin{array}{l}\text { provide basic explanation, basic support, interference, advanced clarification, } \\
\text { and strategy and tactics. After analyzing students' answers, the average score } \\
\text { for providing basic explanation was } 3.31 \text {, building basic supports was } 3.59 \text {, } \\
\text { inferencing was } 3.26 \text {, providing advanced explanation was } 3.88 \text {, and utilizing } \\
\text { strategies and tactics was } 3.41 \text {. Students' HOTS was high with the average } \\
\text { scores in the } 40-60 \text { interval. Therefore, students' critical thinking skills were } \\
\text { sufficient, which affected students' HOTS in science learning. }\end{array}$ \\
\hline
\end{tabular}

(c) 2021 Physics Education Department, UIN Raden Intan Lampung, Indonesia.

\section{INTRODUCTION}

Education must accustom students to possess HOTS (Higher-Order Thinking Skills) which consists of analyzing, evaluating, and creating. However, education is still limited to remembering, understanding, and applying what is known as LOTS or low-order thinking skills (Mislia et al., 2019). HOTS-based learning is essential to face $21^{\text {st }}$-century education era (Sholihah \& Lastariwati, 2020). Indonesia is ranked low on PISA (The Program for International Student Assessment). PISA report for 2018 states that Indonesia was the $74^{\text {th }}$ position out of 79 countries that participated in the assessment (Hewi \& Shaleh, 2020).

Education in Indonesia has implemented Bloom's taxonomy in the learning as outlined in the curriculum. The curriculum can also be used as a tool for teachers during the learning process (Astalini et al., 2018). Education is based on the development of the cognitive level of Bloom's taxonomy. The higher the student's cognitive level, the smarter they can be.

Science is not only studied to determine natural phenomena, but also to provide clues about the future state of nature. Science is also learning that takes place at every level according to the development of each student. In science learning, there are technological activities in the form of planning and manufacturing.

Stupple et al., (2017) states that students' cognitive skills can be viewed from their critical thinking skills. Critical thinking skills are complex thinking skills using logical reasoning that can be measured through objective tests. In critical thinking skills, 
students are required to analyze arguments, conclude using inductive or deductive reasoning, assess or evaluate, and decide or solve problems (Melida et al., 2016). The critical thinking skill is part of higher-order thinking skills (Susana, 2015). Therefore, it is essential for educators to improve the students' cognitive skills.

Padmanabha (2018) claims that critical thinking can be described analytically based on rational discourse with careful and rigorous investigation and approach. Dewey in Thompson (2011) reveals that one of most important skill for problem-solving, investigation, and discovery is critical thinking. According to Lestari (2014), when critical thinking is developed, a person tends to seek the truth, thinks divergent (open and tolerant of new ideas), analyzes problems well, thinks systematically, full of curiosity, mature in thinking, and can think independently. It means that critical thinking skills are important and need to be nurtured from an early age, especially in elementary schools. Thinking skills can be influenced by learning methods (Astalini, Kurniawan, \& Sumaryanti, 2018). Teachers are needed to provide effective learning methods to foster students' thinking skills.

Physics learning is successful if the achievement of the learning objectives is satisfying. Formally, the objectives of learning physics in integrated science do not only emphasize cognitive aspects, but also the ability to solve physics problems (Nofitasari \& Sihombing, 2017). Enabling students to think critically in solving physics problems is an expected outcome of science education (Rahayuni, 2016). Critical thinking skills play an important role in analyzing thoughts, arguments, problems carefully based on the credibility of data and information sources; trying to properly assess thoughts, arguments, problems; able to logically solve problems in various situations and make decisions based on consideration of relevant evidence and facts. Ritdamaya et al., (2016) explain that individual's critical thinking skills can be done using authentic assessment results.

Learning critical thinking skills can be carried out by educators using constructivist learning strategies that can empower critical thinking skills (Pratama \& Prastyaningrum, 2016). This thinking skill is closely related to the learning demanded by the world of education, namely learning based on higherorder thinking skills (Fitri et al., 2017). Sarwi et al., (2012) explain the scope of critical thinking, namely: 1) understanding arguments and believing in them, 2) assessing arguments and believing in them, and 3) developing and defending arguments with strong support and confidence.

Physics learning to understand the concept of refraction of the lens is still very low (Wahyuni, 2015). Besides, the students cannot solve problems in the field of physics. Therefore, teachers as educators are expected to facilitate the development of cognitive abilities and critical thinking skills (Nurazizah et al., 2017). It is necessary to know how the critical thinking skills are related to the concept of lens's refraction in science subjects in junior high school.

Several relevant studies have been conducted by several researchers related to critical thinking skills (Whalen \& Paez, 2020; Leest \& Wolbers, 2020; Ramdhani et al., 2020). These three studies discuss efforts to improve students' critical thinking skills through learning models. The results of this research indicate that the scientific learning model can improve students' critical thinking skills.

This research was conducted at SMPN 22 Jambi City. Usually, students' critical thinking was only pursued through learning activities.

\section{METHODS}

This research employed a mixed research method by combining quantitative and qualitative research approaches.

The population of this research were students of SMPN 22 Jambi City, while the research subjects were the 13-14 years old 
students. The subject was determined by the quota sampling technique (Hermawan \& Yusran, 2017). The quota sampling technique was carried out on the basis of the number or quota determined by the researcher (Nasrudin, 2019). Therefore, the selected research subjects consisted of 58 students. The subjects of this research were the eighth-grade students of SMPN 22 Jambi City in the even semester of the 2019/2020 academic year.

This research uses two instruments: the quantitative research instruments and the qualitative research instruments. For the quantitative approach, the instrument used was a description test with a total of 10 questions. The critical thinking test requires students to compile and state their answers in their own words (Ozkan \& Ozaslan, 2018). The test's description was adopted from the research by Pradana et al., (2017) regarding the development of tests of critical thinking skills in optical geometry material. The qualitative approach instruments were teacher and student interview sheets with six questions for the teacher and five questions for students. The interviews were conducted to add information from research subjects related to how were active the students in the learning process. The interview questions for the teacher were as follows:

1. During the learning process, are the students active in asking questions?

2. Before the teacher gives examples of material in everyday life, can the students give examples first?

3. During the first lesson where the teacher presents a picture, can the students explain part of the picture?

4. At the end of the lesson, can the students conclude the learning?

5. Can students find solutions if there are problems related to everyday life to solve?

6. Do students always ask other friends for their opinions if there is an answer that is still in doubt?
The interview with the teachers was used to strengthen the results of quantitative analysis. The critical thinking indicators in the description test can be seen in Table 1

Table 1. Critical Thinking Indicators of the Description Test

\begin{tabular}{cll}
\hline Variable & Indicators & \multicolumn{1}{c}{ No. } \\
\hline \multirow{2}{*}{ Critical } & Provide a basic & $1 \& 2$ \\
explanking & Provide basic & $3 \& 4$ \\
& supports & \\
& Inference & $5 \& 6$ \\
& $\begin{array}{l}\text { advanced } \\
\text { clarification }\end{array}$ & $7 \& 8$ \\
& Strategy and tactics & $9 \& 10$ \\
\hline
\end{tabular}

The data analysis technique used was the descriptive statistics. The data analysis technique was carried out with an explanatory research design. The quantitative data or the test's results were analyzed using SPSS 21 version. Then, the quantitative results were strengthened by the narrative from the interview results. Explanatory design analysis technique is research that prioritizes quantitative data analysis followed by strengthening the results of quantitative data analysis using quantitative data analysis.

Data analysis of students' critical thinking skills was performed based on interval calculations of a Likert scale with four options. The intervals and categories of critical thinking skills were adapted from research by Lestari et al., (2020) that can be seen in Table 2.

Table 2. Intervals and Categories of Critical Thinking Skills

\begin{tabular}{cc}
\hline Interval & Category \\
\hline $1-1.5$ & Poor \\
$1.6-3$ & Low \\
$3.1-4.5$ & High \\
$4.6-6$ & Excellent \\
\hline
\end{tabular}


The flowchart of this research can be seen in Figure 1.

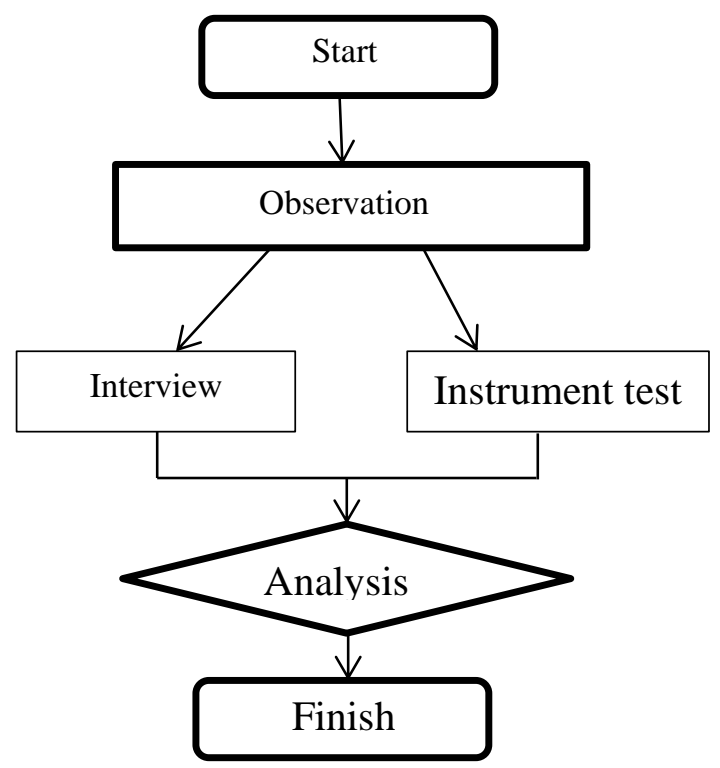

Figure 1. The Flowchart of the Research

Based on Figure 1, the research begins with observations by interviewing science subject teachers related to science learning activities in class. Then, the researchers provide critical thinking skills test questions to students. Finally, the researchers interview two students regarding learning activities in class. The steps were chosen based on the objectives of the research. The interviewed students were those who were most active and ranked first in the class and the students who ranked last in the class. The observation results were analyzed using the SPSS version 21.

\section{RESULTS AND DISCUSSION}

The results of this research contained a descriptive discussion of the students' skills by looking at each indicator of critical thinking skills. The test was given a minimum score of 0 and a maximum score of 4. The results of the students' critical thinking skills test can be seen in Table 3 .
Table 3. The Description of Critical Thinking Skill on Providing Basic Explanation Indicator

\begin{tabular}{ccccc}
\hline Indicator & Interval & $\mathbf{( \% )}$ & & $\mathbf{N}$ \\
\hline & & & Sum & 58 \\
Provide a & $1,0-1,5$ & 0 & Mean & 3,31 \\
basic & $3,1-4,0$ & 8,6 & Median & 3,00 \\
explanation & $4,6-6,0$ & 51,7 & mode & 3 \\
& & 39,7 & Minimum & 2 \\
& & & Maximum & 4 \\
& & & St. Deviasi & 0,627 \\
\hline
\end{tabular}

Table 3 reveals that out of 58 tested students $86.2 \%$ or 50 students had high critical thinking skills category based on an average score of 3.34 which belonged to the high category. The remaining $13.8 \%$ or 8 students were in the low category. The average value of critical thinking skills was 3.34, the median was 3.00, the mode was 3 , the lowest score was 2 , the highest score was 3 , and the standard deviation was 0.358. Students must be trained intensively and repeatedly to achieve high-level thinking abilities. There needs to be a change from conventional teacher-centered models to student-centered models.

The researchers also analyzed students' critical thinking skills based on five indicators. The first indicator is providing a basic explanation of the questions to be solved. For this indicator, there were two questions used, namely items 1 and 2. For providing basic explanation indicator, the sub-indicators analyzed were analyzing the arguments in the questions can be seen in Table 4.

Table 4. The Description of Critical Thinking Skills for Providing a Basic Explanation Indicator

\begin{tabular}{lcclc}
\hline Variable & Interval & $(\%)$ & $\mathbf{N}$ \\
\hline & & & & 58 \\
& & & Sum & 3,34 \\
Critical & $1,0-1,5$ & 0 & Mean & Median \\
Thinking & $1,6-3,0$ & 13,8 & mode & 3 \\
& $3,1-4,5$ & 86,2 & Minimum & 2 \\
& $4,6-6,0$ & 0 & Maximum & 3 \\
& & & St. Deviasi & 0,358 \\
\hline
\end{tabular}


Table 4 presents the results of critical thinking skills for providing basic explanation indicator. Of the 58 students, $8.6 \%$ or 5 students could provide poor basic explanations, $51.7 \%$ or 30 students could provide good basic explanations, and the remaining $39.7 \%$ or 23 students could provide excellent basic explanations. On average, students could provide high basic explanations for essay questions because the average score was 3.31, the media value was 3.00 , the mode value was 3 , the minimum value was 2 , the maximum value was 4 , and the standard deviation was 0.627 .

The second indicator is building basic skills. Building basic skills on the essay test consisted of two questions. In building basic skills, the sub-indicators are expected to use the same procedure. The results of the descriptive analysis can see on Table 5.

Table 5. The Description of Critical Thinking Skills on Building Basic Skills Indicator

\begin{tabular}{ccccc}
\hline Indicator & Interval & $\mathbf{( \% )}$ & & \\
\hline & & & Sum & 58 \\
& $1,0-1,5$ & 1.7 & Mean & 3,59 \\
Basic & $1,6-3,0$ & 1.7 & Median & 4,00 \\
support & $3,1-4,5$ & 32.8 & mode & 4 \\
& $4,6-6,0$ & 63.8 & Minimum & 1 \\
& & & Maximum & 4 \\
& & & St. Deviasi & 0,622
\end{tabular}

The second indicator obtained that $1.7 \%$ or 1 student who could build high basic skills, $1.7 \%$ or 1 person could not build basic skills, $32.8 \%$ or 19 students could build high basic skills, and the remaining $63.8 \%$ or 37 students could build excellent basic skills. The average value obtained was 3.59 which belonged to the good category. The mean value was 3.59 , the median value was 4.00 , the mode value was 4 , the minimum score was 1 and the maximum score was 4 , and the standard deviation was 0.622 .

The third critical thinking indicator was inferencing. This indicator consisted of two questions, namely numbers 5 and 6 . The critical thinking skills for the inferencing indicator can see on Table 6 .
Table 6. The Descriptive of Critical Thinking Skills on Interference Indicator

\begin{tabular}{ccccc}
\hline Indicator & Interval & $\mathbf{( \% )}$ & & \\
\hline & & & Sum & 58 \\
& & & Mean & 3,26 \\
& $1,0-1,5$ & 0 & Median & 3,00 \\
Inference & $1,6-3,0$ & 6.9 & mode & 3 \\
& $3,1-4,5$ & 60.3 & Minimum & 2 \\
& $4,6-6,0$ & 32.8 & Maximum & 4 \\
& & & St. & 0,579 \\
& & \multicolumn{3}{c}{ Deviasi } \\
\hline
\end{tabular}

Table 6 presents the results of the descriptive analysis for the inferencing indicator of critical thinking skills. The students are expected to deduce the physics questions. The results showed that $6.9 \%$ of students had poor inference skills, $60.3 \%$ or 35 students had high inference skills, and the remaining $32.8 \%$ or 19 students had excellent inference skills. The average value was 3.26 , the median value was 3.00 , the mode value was 3 , the minimum value was 2 , the maximum score was 4 , and the standard deviation value was 0.579 .

Critical thinking skills also have indicators to provide advanced clarification. This indicator consisted of two questions, namely questions number 7 and 8 . The students are expected to identify assumptions.

Table 7. The Description of Critical Thinking Skills on the Advanced Clarification Indicator

\begin{tabular}{lcccc}
\hline Indicator & Interval & $\mathbf{( \% )}$ & & $\mathbf{N}$ \\
\hline & & & Sum & 58 \\
& & & Mean & 3,88 \\
Advanced & $1,0-1,5$ & 0 & Median & 3,00 \\
clarificati & $1,6-3,0$ & 27.6 & mode & 3 \\
on & $3,1-4,5$ & 56.9 & Minimum & 2 \\
& $4,6-6,0$ & 15.5 & Maximum & 4 \\
& & & St. Deviasi & 0,651 \\
\hline
\end{tabular}

Table 7 shows that $27.6 \%$ or 16 students were in the poor advanced clarification category, $56.9 \%$ or 33 were in the high advanced clarification category, and the remaining $15.5 \%$ or 9 students were in the excellent advanced clarification category. The average value was 3.88 , the median value was 3.00 , the mode value was 3 , the 
minimum value was 2 , the maximum value was 4 , and the standard deviation value was 0.651 .

The fifth indicator is strategy and tactics. This indicator consisted of two questions, namely numbers 9 and 10. Strategies and tactics required the students to provide innovation to the problems being tested. The following are the results of the last indicator.

Table 8. The Description of Critical Thinking Skills on the Strategy and Tactics Indicator

\begin{tabular}{cclcc}
\hline Indicator & Interval & $\mathbf{( \% )}$ & & $\mathbf{N}$ \\
\hline & & & Sum & 58 \\
Strategy & $1,0-1,5$ & 0 & Mean & 3,43 \\
and & $1,6-3,0$ & 5.2 & Median & 3,00 \\
tactics & $3,1-4,5$ & 46.6 & mode & 4 \\
& $4,6-6,0$ & 48.2 & Minimum & 2 \\
& & & Maximum & 4 \\
& & & St. Deviasi & 0,596 \\
\hline
\end{tabular}

In the strategies and tactics indicator, $5.2 \%$ or 3 students had poor strategy and tactics, $46.6 \%$ or 27 people had high stategies and tactics, and the remaining 28 students or $48.2 \%$ had excellent strategies and tactics. The average value was 3.43 , the median value was 3.00 , the mode value was 4 , the minimum value was 2 , the maximum value was 4 , and the standard deviation value was 0.596 .

The comparison of the average value of each indicator is illustrated in Figure 2.

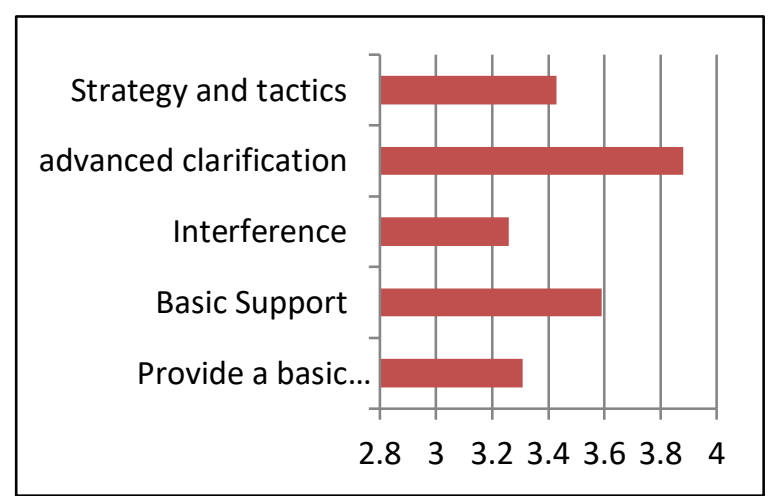

Figure 2. The Comparison of Each Critical Thinking Indicator

Based on Figure 2, advance clarification indicator is the dominant indicator mastered by the students.
Based on interviews with science subject teachers, the students were active to know more about the material presented by the teacher. Besides, the students could connect daily activities or objects related to the material being taught. The students sometimes could provide conclusions related to the benefits of the material in everyday life. The students communicated with their peers or classmates to get more information on the material presented by the teacher. The students were more active in increasing their knowledge by not just waiting for input or answers from the teacher. It was good for students to hone their critical thinking skills.

Setyawan et al., (2020) states that HOTS are learning with various possibilities to solve various problems in natural science. In HOTS-based learning, there are four components required: the critical thinking skills, the creative thinking skills, the logical thinking skills, and the ability to provide solutions (Ariyana \& Pujiastuti, 2018). Responding to the challenges of the $21^{\text {st }}$ century, especially in integrating science subjects, it is essential to develop critical thinking skills. According to Putri and Ghufron (2019), critical thinking is an active disciplinary process of conceptualizing, applying, analyzing, systemizing, and/or evaluating information gathered from skilled observation or communication.

Critical thinking is essential for every student to face $21^{\text {st }}$-century education. The students are required to develop their skills. Therefore, it is essential to improve students' skills in critical thinking, especially in science subjects such as physics.

The results of research on students' critical thinking skills at SMPN 22 Jambi City were focused on their thinking abilities. In analyzing the critical thinking skills, 10 description questions were administered. Each question contained critical thinking skills indicator. The first indicator is the ability to provide basic explanations. In this indicator, many students belonged to the high category. The questions were story questions that asked students to provide arguments for 
the problems contained in questions number 1 and 2. The average score of students' abilities to provide basic explanations was 3.31 from a maximum score of 6 . The results indicated that the students already had the ability to think critically. This result might be caused by the learning environment at SMPN 22 Jambi City which supports the students to actively learn and improve their cognitive abilities.

Another indicator tested was building basic skills. The questions contained images where the students were asked to provide an explanation. This indicator provided an overview of what happens to the image on the single description test. The score obtained was 3.59. The result indicated that the students possessed a high skill building ability.

The third indicator was inferencing. The explanatory questions were presented in the form of pictures where the students were asked to provide conclusions. This indicator obtained an average score of 3.26 which indicated that the students had high inferencing abilities.

The fourth indicator was providing advanced clarification. The average score obtained in this indicator was 3.88. Meanwhile, the fifth indicator was strategy and tactics. The average score obtained in this indicator was 3.43. The result indicated that the students could use good calculations for the questions given.

Natural science is closer to science learning and scientific thinking in science subjects (Lehavi \& Eylon, 2018). Five questions were asked to students regarding critical thinking skills whether science is related to everyday life and whether in science learning, the students are active in asking questions to the teacher about the material presented. Most of the students answered that they were interested in science learning because science learning could be connected to everyday life. During the class, they always prepare the questions they want to ask their teacher or classmates. Based on the results of interviews with students, it was known that the learning process was done through conventional learning where the teacher explained, and the students took notes and did practice questions. There were few opportunities for students to be active and provide arguments in ongoing learning.

Research conducted by Leest and Wolbers (2020) analyze the critical thinking skills of the university students in the Netherlands related to the influence of the critical thinking skills in getting the chosen opportunity in a higher education major. Whalen et al., (2020) conducted research on a large scope of critical thinking skills and was carried out on university students. Ramdani et al., (2020) show that the highest indicator is providing advanced clarification compared to other indicators of critical thinking skills. The researchers found similar results that the skills to provide advanced clarification have the highest value compared to other indicators of critical thinking skills. Based on the results of research, students with high critical thinking skills tend to be in high level thinking processes or higher-other thinking skills. This result is based on the students' work on HOTS questions tested by the researcher.

\section{CONCLUSION AND SUGGESTION}

The average score for providing basic explanation was 3.31, building basic supports was 3.59 , inferencing was 3.26 , providing advanced explanation was 3.88 , and utilizing strategies and tactics was 3.41. Students' HOTS was high with the average scores in the 40-60 interval. Therefore, students' critical thinking skills were sufficient, which affected students' HOTS in science learning.

This research can be used as a reference for the world of education, especially science subjects so that students are accustomed to stating opinions in every lesson to improve their critical thinking skills. The results of this research can be a reference for further research, especially in the development of teaching materials that can improve students' critical thinking skills. 


\section{REFERENCES.}

Ariyana, Y., Pujiastuti, A., Bestary, R. \& Zamroni. (2018). Buku pegangan pembelajaran berorieantasi pada keterampilan berpikir tingkat tinggi. Kementerian Pendidikan dan Kebudayaan.

Astalini, A., Kurniawan, D. A., Melsayanti, R., \& Destianti, A. (2018). Sikap terhadap mata pelajaran IPA di SMP se-kabupaten Muaro Jambi. Lentera Pendidikan: Jurnal Ilmu Tarbiyah dan Keguruan, 2l(2), 214-227. https://doi.org/10.24252/lp.2018v21n2i7

Astalini, A., Kurniawan, D. A., \& Sumaryanti, S. (2018). Sikap siswa terhadap pelajaran fisika di SMAN Kabupaten Batanghari. JIPF (Jurnal Ilmu Pendidikan Fisika), 3(2), 59-64. https://doi.org/10.26737/jipf.v3i2.694

Fitri, S. G. S, Hendriyani, M. E., Sari, I. J. (2017). The development of biotechnology's learning instruments oriented higher-order thinking and the utilization of natural resources tunda's island potential, Jurnal Penelitian dan Pembelajaran IPA. 3(1), 41-52.

Hewi, L., \& Shaleh, M. (2020). Penguatan peran lembaga PAUD untuk the programme for international student assesment. Jurnal Tunas Siliwangi, 6(2), 63-70.

Leest, B., \& Wolbers, M. H. (2020). Critical thinking, creativity and study results as predictors of selection for and successful completion of excellence programmes in dutch higher education institutions programmes in dutch higher education institutions. European Journal of Higher Education, $1-15$. https://doi.org/10.1080/21568235.2020.1 850310

Lehavi, Y., \& Eylon, B.-S. (2018). Integrating science education research and history and philosophy of science in developing an energy curriculum. Springer. https://doi.org/10.1007/978-3-31962616-1_9

Lestari, D. A., Ariyanto, J., \& Harlita, H. (2020). Perbandingan keterampilan berpikir kritis siswa dengan model problem-based learning dan numbered heads together berbasis student created case studies. Edusains, 12(1), 9-19. https://doi.org/10.15408/es.v12i1.12291

Lestari, R. P. (2014). Penerapan pendekatan keterampilan proses sains dalam model pembelajaran guided discovery pada materi suhu dan kalor terhadap hasil belajar siswa di SMAN 1 Sukomoro. Inovasi Pendidikan Fisika, 3(2), 60-64.

Melida, H. N., Sinaga, P., \& Feranie, S. (2016). Implementasi strategi writing to learn untuk meningkatkan kemampuan kognitif dan keterampilan berpikir kritis siswa sma pada materi hukum newton. Jurnal Penelitian \& Pengembangan Pendidikan Fisika, 2(2), 31-38.

Mislia, T. S., Indartono, S., \& Mallisa, V. (2019). Improving critical thinking among junior high school students through assessment of higher-level thinking skills. Advances In Social Science, Education and Humanities Research, 323(1), 326-333.

Nofitasari, I., \& Sihombing, Y. (2017). Deskripsi kesulitan belajar peserta didik dan faktor penyebabnya dalam memahami materi listrik dinamis kelas $\mathrm{X}$ SMA Negeri 2 Bengkayang. Jurnal Penelitian Fisika Dan Aplikasinya (JPFA), $\quad$ 7(1), 44-53. https://doi.org/10.26740/jpfa.v7n1.p4453

Nurazizah, S., Sinaga, P., \& Jauhari, A. (2017). Profil kemampuan kognitif dan keterampilan berpikir kritis siswa sma pada materi usaha dan energi. Jurnal Penelitian \& Pengembangan Pendidikan Fisika, 3(2), 197-202.

Ozkan, Y. O., \& Ozaslan, N. (2018). Student achievement in Turkey, according to question types used in PISA 2003-2012 mathematic literacy tests. International Journal of Evaluation And Research In Education (IJERE), 7(1), 57-64. https://doi.org/10.11591/ijere.v7i1.11045

Padmanabha. (2018). Critical thinking: Conceptual framework. Review Papers, 11(4), 45-53.

Pradana, S. D. S., Parno, P., \& Handayanto, S. K. (2017). Pengembangan tes 
kemampuan berpikir kritis pada materi optik geometri untuk mahasiswa fisika. Jurnal Penelitian dan Evaluasi Pendidikan, 21(1), 51-64. https://doi.org/10.21831/pep.v21i1.1313 9

Pratama, H., \& Prastyaningrum, I. (2016). Pengaruh model pembelajaran project based learning berbantuan media pembelajaran pembangkit listrik tenaga mikrohidro terhadap kemampuan berpikir kritis. Jurnal Penelitian Fisika dan Aplikasinya, 6(2), 44-50.

Putri, R., \& Ghufron, A. (2019). Efektivitas strategi the power of two terhadap kecakapan critical thinking siswa. Jurnal Kependidikan, 3(2), 194-206.

Rahayuni, G. (2016). Hubungan keterampilan berpikir kritis dan literasi sains pada pembelajaran IPA terpadu dengan model PBM dan STM. Jurnal Penelitian dan Pembelajaran IPA, 2(2), 131-146.

Ramdani, A., Jufri, A. W., \& Setiadi, D. (2020). Kemampuan berpikir kritis dan penguasaan konsep dasar IPA peserta didik. Jurnal Penelitian Pendidikan IPA, 6(1), 119-124. https://doi.org/10.29303/jppipa.v6i1.388

Ritdamaya, D. \& Suhandi, A. (2016). Konstruksi instrumen tes keterampilan berpikir kritis terkait materi suhu dan kalor. Jurnal Penelitian \& Pengembangan Pendidikan Fisika 2(2), 87-96.

Sarwi, Rusilowati, A., \& Khanafiyah, S. (2012). Implementasi model eksperimen gelombang open-inquiry untuk mengembangkan keterampilan. Jurnal Pendidikan Fisika Indonesia, 9 (1), 4150.

Setyawan, F., Prasetyo, P. W., \& Nurnugroho, B. A. (2020). Developing complex analysis textbook to enhance students' critical thinking. Journal of Research and
Advances in Mathematics Education. 5(1), 26-37. https://doi.org/10.23917/jramathedu.v5i1 .8741

Sholihah, T. M., \& Lastariwati, B. (2020). Problem based learning to increase competence of critical thinking and problem solving. Journal of Education and Learning (EduLearn), 14(1), 148154.

https://doi.org/10.11591/edulearn.v14i1. 13772

Stupple, E. J. N., Maratos, F. A., Elander, J., Hunt, T. E., Cheung, K. Y. F., \& Aubeeluck, A. V. (2017). Development of the critical thinking toolkit (critt): A measure of student attitudes and beliefs about critical thinking. Thinking Skills and Creativity, 23, 91-100. https://doi.org/10.1016/j.tsc.2016.11.007

Susana, E. S. H. (2015). Analisis didaktis berdasarkan kemampuan kognitif dan keterampilan berpikir kritis siswa pada materi kalor. 1(2), 39-44.

Thompson, C. (2011). Critical Thinking across the curriculum: Process over output. International Journal of Humanities and Social Science, 1(9), 1-7.

Wahyuni, A. S. A. (2015). Konsepsi dan miskonsepsi siswa, mahasiswa calon guru, dan guru pada topik cahaya dalam pembelajaran fisika. Jurnal Pendidikan Fisika, 6(3), 235-250.

Whalen, K., Paez, A., \& Whalen, K. (2020). Student perceptions of reflection and the acquisition of higher-order thinking skills in a university sustainability course. Journal of Geography in Higher Education, 45(1), 1-20. https://doi.org/10.1080/03098265.2020.1 804843 